\title{
Delaying farrowing using intravaginal devices impregnated with progestagen does not affect the proportion of piglets born alive
}

\author{
O atraso do parto utilizando dispositivos intravaginais impregnados com progestágeno não afeta \\ a proporção de leitões nascidos vivos
}

\author{
Gabriel Fernando Freling ${ }^{\mathrm{I}}$ Bernardo Garziera Gasperin ${ }^{\mathrm{I}}$ Rogério Ferreira $^{\mathrm{II}}$ \\ Matheus Pedroti Cesaro I João Francisco Oliveira' ${ }^{I}$ Vilceu Bordignon ${ }^{\mathrm{III}}$ \\ Paulo Bayard Dias Gonçalves ${ }^{I}$
}

\section{ABSTRACT}

The objective of this study was to evaluate the efficiency of progestagen intravaginal devices (IVDs) in preventing parturition in sows by determining the effect of delaying parturition on the alive/total born piglets ratio. Evaluations of IVDs containing $0.5,1.0$ or $1.5 \mathrm{~g}$ progesterone $(P 4)$ showed they were not effective in delaying parturition at any dosage tested. In a second experiment, seventy-five sows at day 112 of pregnancy were equally distributed ( $n=15$ per group) in the following treatments: prostaglandin (PGF2 $\alpha ; 250 \mu \mathrm{g}$ sodium cloprostenol; control group) or PGF $2 \alpha$ and simultaneous insertion of an IVD containing medroxyprogesterone acetate (MPA) for 48h. Control sows initiated labor $27.7 \pm 1.6 \mathrm{~h}$ after PGF $2 \alpha$ injection. The mean time ( \pm SEM) between $P G F 2 \alpha$ administration and parturition was $72.1 \pm 8.8 \mathrm{~h}$, 72.7 $\pm 3.8 \mathrm{~h}, 82.7 \pm 7.1 \mathrm{~h}$ and $81.8 \pm 3.5 \mathrm{~h}$ for MPA 100, 200, 400 and $800 \mathrm{mg}$, respectively, differing from control group $(P<0.05)$. To evaluate the effect of delaying parturition on the alive/total born piglets ratio at birth, sows between days 109 and 112 of gestation received IVDs containing $800 \mathrm{mg}$ MPA (on Thursdays) for $72 \mathrm{~h}$ to prevent parturition in weekends and then were treated with $P G F 2 \alpha$ at the time of device withdrawal (on Sundays). The alive/total born piglets ratio was $89.0 \pm 1.6,90.1 \pm 1.2$ and $89.0 \pm 1.5 \%$ for control (Normal group; $n=57$ sows), $P G F 2 \alpha$-induced (Induced group: $n=57$ sows), and IVD $+P G F 2 \alpha$-induced (MPA800 group, $n=56$ sows) groups, respectively $(P>0.05)$. These findings confirm that IVDs impregnated with MPA can effectively prevent parturition in sows without affecting the alive/total born piglets ratio and therefore represent an alternative to avoid weekend farrowing in swine herds.

Key words: programmed farrowing, alive/total born piglets ratio, medroxyprogesterone acetate.

\section{RESUMO}

O objetivo do presente estudo foi avaliar a eficiência de dispositivos intravaginais (DIVs) contendo progestágeno na prevenção do parto e determinar o efeito do atraso do parto sobre a proporção de leitões vivos/nascidos totais. DIVs contendo $0,5,1,0$ ou 1,5g de progesterona (P4) não foram eficientes na prevenção do parto em nenhuma das doses. No experimento 2, setenta e cinco porcas aos 112 dias de gestação foram equilibradamente distribuidas ( $n=15$ por grupo) nos seguintes tratamentos: prostaglandina (PGF2 $\alpha ; 250 \mu \mathrm{g}$ cloprostenol sódico; grupo controle) ou PGF $2 \alpha$ e simultânea inserção de DIV contendo acetato de medroxiprogesterona (MAP) por 48 h. Fêmeas

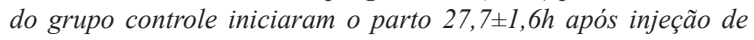
$P G F 2 \alpha$. O tempo médio entre a administração de $P G F 2 \alpha$ e início do parto foi $72,1 \pm 8,8 \mathrm{~h}, 72,7 \pm 3,8 \mathrm{~h}, 82,7 \pm 7,1 \mathrm{~h}$ e $81,8 \pm 3,5 \mathrm{~h}$ para os grupos MAP 100, 200, 400 e $800 \mathrm{mg}$, respectivamente, diferindo do grupo controle $(P<0,05)$. Para avaliar o efeito da inibição do parto sobre a proporção de leitões nascidos vivos, porcas entre 109 e 112 dias de gestação receberam DIVs contendo $800 \mathrm{mg}$ MAP (quintas-feiras) por $72 \mathrm{~h}$ para prevenir o parto aos finais de semana e foram tratadas com $P G F 2 \alpha$ no momento da retirada dos DIV (aos domingos). A razão leitões vivos/nascidos totais foi 89,0 $1,6,90,1 \pm 1,2$ e 89,0 $1,5 \%$ nos grupos controle (Normal; $n=57$ porcas), induzido com PGF $2 \alpha$ (Induzido; $n=57$ porcas) e $P G F 2 \alpha+D I V$ (MPA800; $n=56$ porcas), respectivamente $(P>0,05)$. Esses resultados confirmam que DIVs contendo MAP podem efetivamente inibir o início do parto em porcas sem afetar a proporção de leitões nascidos vivos e, portanto, representam uma alternativa para evitar partos aos finais de semana.

Palavras-chave: indução de parto, proporção de leitões vivos, acetato de medroxiprogesterona.

\section{INTRODUCTION}

Supervision of sow parturition is crucial to reduce mortality of live-born piglets because it

IDepartamento de Clínica de Grandes Animais, Laboratório de Biotecnologia e Reprodução Animal, Universidade Federal de Santa Maria (UFSM), Avenida Roraima, n 1000, Prédio 97, sala 416, 97105-900, Santa Maria, RS, Brasil. E-mail: bggasperin@gmail.com. *Autor para correspondência.

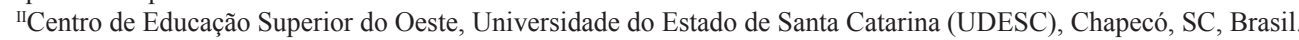

IIIDepartment of Animal Science, McGill University, Ste-Anne-De-Bellevue, QC, Canada. 
decreases the number of piglets starving to death, ensuring colostrum intake. Furthermore, ensuring that all the piglets are fed immediately after birth decreases the number of piglets being crushed by the sow (HOLYOAKE et al., 1995), probably because they spend less time in close proximity to the sow. However, the effective care of piglets requires a fulltime presence of workers in the maternity. Thus, programing the moment of parturition facilitates its supervision. Currently, the control of parturition in sows is based on the use of luteolytic drugs, which anticipates the parturition time through an acute decrease in progesterone levels (KING \& WATHES, 1989).

Although PGF2 $\alpha$ treatment is considered an effective practice to concentrate parturition, it is only recommended for sows that are between days 112 and 114 of gestation (DE RENSIS et al., 2012). Commonly, producers program inseminations and weaning to ensure that females start farrowing, spontaneously or after induction, during week days. Nevertheless, a significant proportion of animals, mainly primiparous and repeat breeder sows, are inseminated at random days, farrowing during weekends. The other alternative to synchronize farrowings consists in maintaining high plasma progesterone levels during late gestation. A protocol that combines these two approaches could further concentrate parturitions to week days, thus facilitating farrowing supervision and the cross-fostering of newborn piglets. Previous studies have evaluated oral progestagen treatments to control the farrowing time (KIRKWOOD et al., 1985; GUTHRIE et al., 1987; WHITELY et al., 1990) and prevent early parturition in sows (VANDERHAEGHE et al., 2011). Most of the studies conducted to control reproductive events in sows were based on the oral supplementation of the synthetic progestagen altrenogest (GUTHRIE et al., 1987; WOOD et al., 1992; PATTERSON et al., 2008; VANDERHAEGHE et al., 2011). However, other orally-administered synthetic progestagens were also tested. For instance, medroxyprogesterone acetate was orally administrated (twice daily) to sows and shown to effectively delay parturition by one day (WHITELY et al., 1990).

Intravaginal devices containing progestagens have been used for estrus induction and synchronization in ruminants for many years. Compared to other methods, the use of IVDs offers a number of advantages that include a better control of the administered dose, the possibility of using orally inactive steroids, and the reduction of labor and animal handling (only insertion and withdrawal) in comparison to multiple oral administrations or intramuscular (i.m.) injections. Recently, it has been described an IVD to promote the slow release of progestagen in swine (GASPERIN et al., 2011). Nevertheless, the intravaginal route for progestagens administration has not been adequately studied for farrowing control in swine. The objectives of the present study were to: a) examine the efficiency of progesterone and medroxyprogesterone acetate in delaying sows' parturition; and b) determine the effect of delaying parturition to prevent farrowings during weekends on the alive/total born piglets ratio.

\section{MATERIAL AND METHODS}

All experimental procedures using animals were reviewed and approved by the Federal University of Santa Maria Animal Care and Use Committee. Experiments were conducted in a commercial swine farm, which have a breeding herd of 400 crossbred sows (Génétiporc - Fertilis 20), located in Rio Grande do Sul State, in the southern region of Brazil. The average gestation length of the herd is $113.9 \pm 0.2$ days. During gestation, all sows used in the following experiments were housed in individual crates measuring $2.2 \mathrm{~m}$ in length and $0.80 \mathrm{~m}$ in width. Intravaginal polyurethane devices (IVDs; 4x4x5cm, density $33 \mathrm{~kg} \mathrm{~m}^{-3}$ ) were prepared and impregnated with different concentrations of progesterone (P4; GenixPurifarma, Anápolis, Brazil) or medroxyprogesterone acetate (MPA; Genix-Purifarma, Anápolis, Brazil). A vaginal speculum measuring $2.5 \mathrm{~cm}$ in diameter and $0.4 \mathrm{~m}$ in length was used to insert the IVDs. Gestation length was calculated taking into account the first insemination. In all experiments, permanent supervision of individual sows at all farrowings was performed by experienced technicians. All piglets born alive were weighed before colostrum intake using a digital scale.

In the first experiment, it was evaluated if IVDs for slow release of progesterone (P4) were capable of maintaining the gestation in swine. Twenty-seven sows at day 112 of pregnancy received polyurethane IVDs containing $0.5(\mathrm{n}=6)$, $1.0(n=6)$ or $1.5 \mathrm{~g} \mathrm{P} 4(\mathrm{n}=10)$ or a silicone intravaginal device for bovine (DIB ${ }^{\circledR}$; Schering-Plough Animal Health, Brazil) containing 1g P4 $(n=5)$ and were simultaneously i.m. treated with PGF $2 \alpha(250 \mu \mathrm{g}$ sodium cloprostenol; Schering-Plough Animal Health, Brazil).

Based on the results from the first experiment, a second experiment was conducted to evaluate if IVDs containing the synthetic progestagen 
MPA were effective in inhibiting PGF2 $\alpha$-induced parturition. Parturition was induced in 75 sows (Landrace X Large White) with an i.m. injection of PGF $2 \alpha(250 \mu \mathrm{g}$ sodium cloprostenol) given at day 112 of pregnancy. Sows were equally distributed $(n=15$ per group) in the following treatments: only PGF $2 \alpha$ (control), or PGF2 $\alpha$ and simultaneous insertion of an IVD containing 100mg (MPA100), 200mg (MPA200), 400mg (MPA400) or 800mg MPA (MPA800). The five groups were balanced for sow parity and the IVDs were removed $48 \mathrm{~h}$ after PGF $2 \alpha$ treatment. All sows were kept under the same housing conditions and the experiment was performed in multiple days during one month, to accumulate 15 sows in each group.

The third experiment was conducted to test a protocol to prevent farrowing on weekends in a commercial swine herd by delaying parturition using IVDs impregnated with MPA (during May 2011 to December 2011). Sows at 113 days of pregnancy ( $n=57$; Induced group) were treated with PGF $2 \alpha$ ( $250 \mu \mathrm{g}$ sodium cloprostenol) on Thursday mornings to initiate parturition on Friday. Sows between days 109 and 112 of pregnancy received IVDs containing 800mg MPA ( $\mathrm{n}=56$; MPA 800 group) on Thursday mornings (10:00 a.m.) for 72h. Devices were removed on Sunday (10:00 a.m.) and PGF2 $\alpha$ was simultaneously administered (i.m.) in all sows. To evaluate the effect on the alive/total born piglets ratio, non-induced sows ( $\mathrm{n}=57$; Normal group) were used as control.

In the first experiment (using P4 IVDs) statistical analysis was not performed because sows initiated parturition before IVD withdrawal in all groups. In experiments 2 and 3, which used MPA IVDs, continuous dependent variables were tested for normal distribution using Shapiro-Wilk test and normalized when necessary. Residuals were also tested for normal distribution. In experiment 2, time between PGF $2 \alpha$ administration and birth of the first piglet, number of piglets born and piglets born alive were recorded and compared by ANOVA, using general linear models GLM and post-hoc analyses of least square-adjusted means were done using Student's t test. In experiment 3 , the alive/total born ratio was analyzed using a generalized linear model with fitted binomial distribution of logit-transformed data. The effect of sow parity on the total number of born piglets, live born piglets and time between IVD withdrawal and parturition was assessed. All continuous data were analyzed using JMP software (SAS Institute Inc., Cary, NC). Data are presented as mean \pm standard error of the mean (SEM).

\section{RESULTS}

The rationale of the first experiment was to test whether exogenous P4 supplementation using IVDs would inhibit parturition after luteolysis. When IVDs containing P4 were inserted at day 112 of pregnancy simultaneously to an i.m. injection of PGF $2 \alpha, 6$ out of 6,5 out of 6 and 9 out of 10 sows farrowed before the removal of the IVD in $0.5,1.0$ and $1.5 \mathrm{~g}$ groups, respectively. Silicone devices containing $1 \mathrm{~g}$ of progesterone were not effective in delaying farrowing, once 2 out of 5 sows initiated farrowing before IVD withdrawal.

In the second experiment, it was evaluated if IVDs containing MPA were effective in maintaining gestation in sows after PGF2 $\alpha$-induced luteolysis. Three sows (20\%) in the MPA100 group began farrowing before IVD removal. One out of 15 sows also initiated parturition in the MPA200 and MPA400 groups. IVDs containing 800mg MPA (MPA800 group) were $100 \%$ effective in preventing farrowing. Control sows initiated farrowing 27.7 \pm 1.6 $\mathrm{h}$ after PGF $2 \alpha$ injection. The mean $( \pm \mathrm{SEM})$ time between PGF2 $\alpha$ administration and the beginning of farrowing was $72.1 \pm 8.8 \mathrm{~h}, 72.7 \pm 3.8 \mathrm{~h}, 82.7 \pm 7.1 \mathrm{~h}$ and $81.8 \pm 3.5 \mathrm{~h}$ for the MPA100, MPA200, MPA400, and MPA800 groups, respectively. The time from PGF $2 \alpha$ administration to farrowing was greater in MPA treated sows in comparison to control sows (Figure 1; $\mathrm{P}<0.01$ ). Increasing the gestation length did not affect farrowing duration, number of live-born piglets, piglet mortality rate and piglet birth weight (Figure 1).

Based on the low efficiency of P4 to delay farrowing, MPA was used in the last experiment. The use of IVDs was tested in a commercial swine herd to establish a protocol to prevent farrowing on weekends. None of the sows submitted to the protocol depicted in figure 2A began farrowing before IVD withdrawal. The mean $( \pm$ SEM) time between PGF $2 \alpha$ administration and parturition in the MPA800 group was $48.6 \pm 3.2 \mathrm{~h}$. Sows initiated farrowing $22 \mathrm{~h}$ after IVD withdrawal and $62.5 \%$ of parturitions occurred between 22 and 48h, 23.2\% between 48 and $72 \mathrm{~h}$ and $14.3 \%$ after $72 \mathrm{~h}$ of IVD withdrawal. The percentage of sows that farrowed in each weekday is shown in figure $2 \mathrm{~B}$. The average number of total born piglets $(14.8 \pm 0.4,14.0 \pm 0.4$ and $14.3 \pm 0.4)$, live born piglets (13.2 $\pm 0.4,12.5 \pm 0.3$ and $12.75 \pm 0.4)$, and the alive/ total born piglets ratios $(89.0 \pm 1.6 \%, 90.1 \pm 1.2 \%$ and $89.0 \pm 1.5 \%)$ did not differ $(\mathrm{P}>0.05)$ between noninduced (Normal group), Induced and MPA800 sows, respectively (Figure 2C). Average rates of death $(8.5 \pm 1.4,6.5 \pm 0.8$ and $6.6 \pm 1.1 \%)$ and mummified 


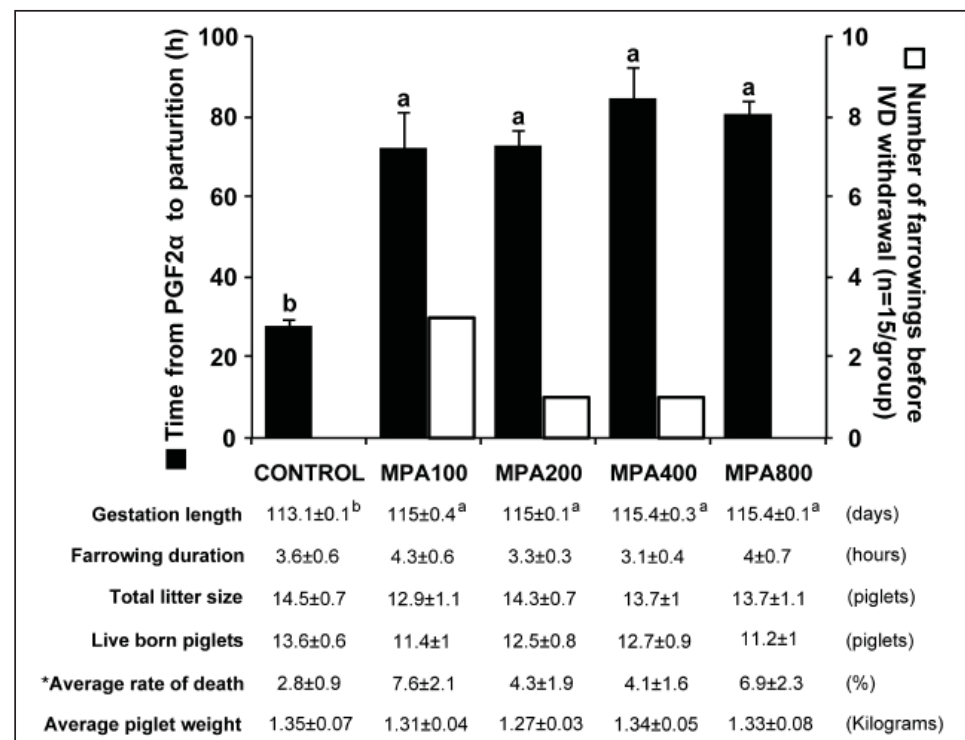

Figure 1 - Time between prostaglandin i.m. administration and beginning of parturition (black bars) and number of sows that initiated farrowing before IVD removal (white bars). Sows (Landrace X Large White; $\mathrm{n}=75$ ) at day 112 of gestation were equally distributed into 5 groups and received an i.m. injection of PGF $2 \alpha(250 \mu \mathrm{g}$ sodium cloprostenol; control group) or PGF2 $\alpha$ plus an IVD containing 100, 200, 400 or $800 \mathrm{mg}$ MPA. Devices were removed $48 \mathrm{~h}$ after PGF $2 \alpha$ treatment. Time between PGF $2 \alpha$ treatment and beginning of parturition was recorded independently of occurring before or after device removal. Reproductive parameters from each group are depicted bellow the graph. *Rate of death was calculated by dividing the number of dead piglets (except mummified) by the total number of piglets born in each litter. Different superscripts indicate statistical difference $(\mathrm{P}<0.05)$ between treatments.

piglets $(2.5 \pm 0.7,3.3 \pm 0.8$ and $4.4 \pm 0.9 \%)$ did not differ $(\mathrm{P}>0.05)$ between Normal, Induced and MPA800 groups, respectively. The farrowing length in MPA800 group was $3.46 \pm 0.2 \mathrm{~h}$. There was no significant effect of sow parity on the total number of born piglets, live born piglets and time between IVD withdrawal and parturition $(\mathrm{P}>0.05)$ in the MPA800 group.

\section{DISCUSSION}

Farrowing supervision is a mandatory practice to reduce the loss of newborn piglets in swine breeding herds, but requires a full-time presence of workers in the maternity, increasing expenses with labour. In the present study it was evaluated a simple and low-cost method for progestagens administration based on the use of IVDs, which proved to be effective to avoid parturitions during weekends with no negative effects on the alive/total born piglets ratio. Deliveries were only observed to occur before IVDs withdrawal in some groups, which was likely a consequence of the lower progestagen levels tested in those groups.
Currently, programmed farrowing is mainly based on the use of luteolytic drugs, which induce labor approximately $24 \mathrm{~h}$ after administration (KING \& WATHES, 1989). However, this practice is only recommended for sows that are between days 112 and 114 of gestation (DE RENSIS et al., 2012). Thus, a significant proportion of animals, mainly primiparous and repeat breeder sows, is not treated and may deliver during weekends. In the present study, the synchrony of parturition after PGF $2 \alpha$ administration in control sows was comparable to previous data using the same protocol (HOLYOAKE et al., 1995), and similar to sows submitted to two injections of PGF2 $\alpha$ (175 $\mu \mathrm{g}$ each) with $6 \mathrm{~h}$ interval, which is thought to increase the luteolytic response (KIRKWOOD \& AHERNE, 1998).

Natural P4 administered intramuscularly from day 108 to 113 (25mg four times daily) of pregnancy was shown to delay farrowing, which occurred at day $115.6 \pm 0.3$ (WILSON et al., 1989). Initially, the effect of P4 supplementation was evaluated using intravaginal polyurethane and commercial silicon devices. However, high 


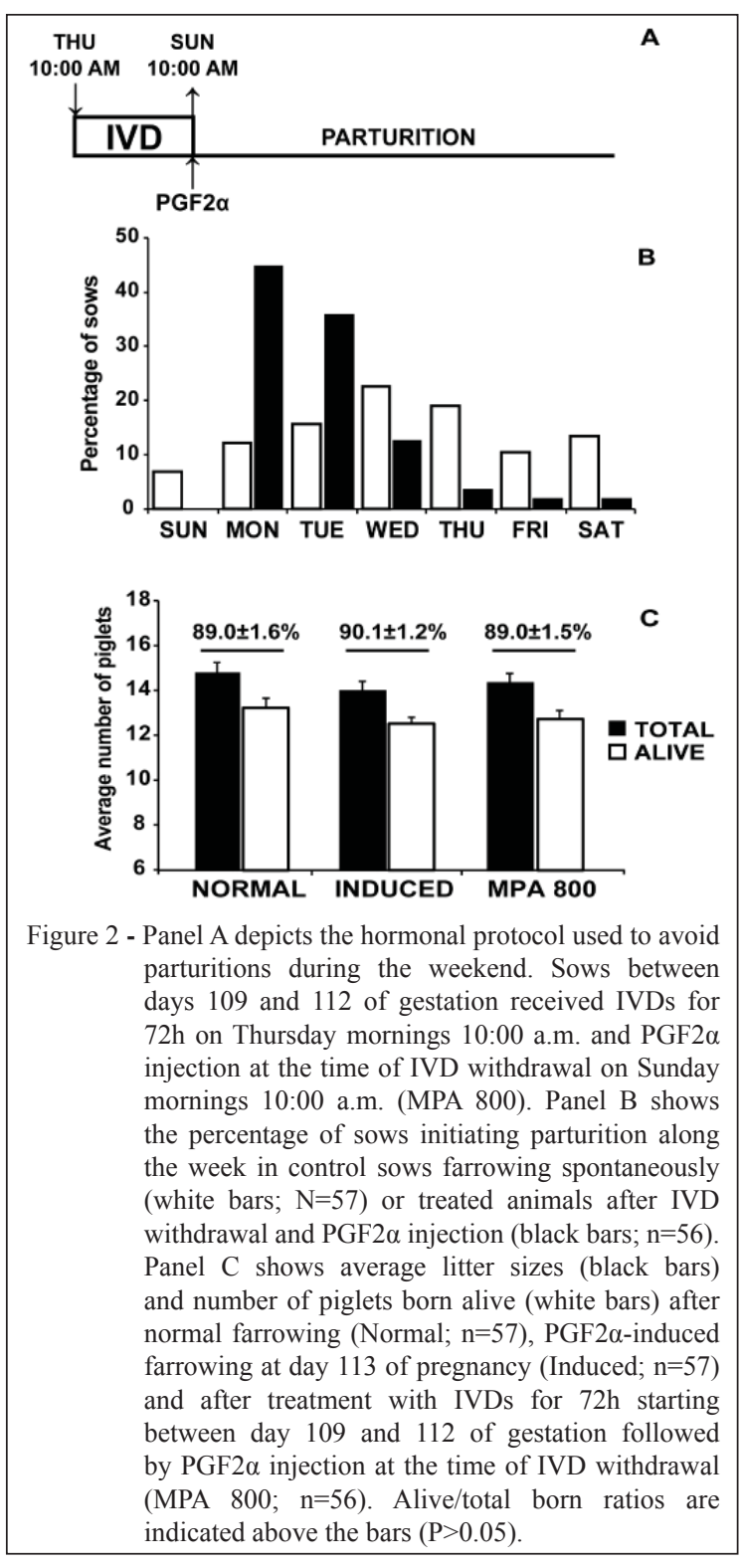

doses of P4 were not effective in preventing sow's parturition. Despite the low number of sows in each group, the aim of the experiment was to identify a P4 dose $100 \%$ effective in preventing parturition. Once none of the doses evaluated was effective, the experiment was conclusive. It seems that intravaginal absorption of $\mathrm{P} 4$ does not effectively provide enough systemic levels to prevent parturition. In support of this possibility, it was observed that even when the P4 dose was increased to $2 \mathrm{~g}$ (data not shown) sows initiated parturition before the IVD withdrawal.

To evaluate if vaginally administered MPA is effective in preventing parturition, farrowing was induced in sows at day 112 of gestation with PGF $2 \alpha$ and concomitantly inserted an IVD containing different doses of MPA. The mean time between PGF2 $\alpha$ administration and farrowing was significantly lower in control than in treated sows, but no significant difference was observed between treated groups. The dose of MPA influenced the number of sows delivering before IVD withdrawal. It was previously shown that orally administered MPA could effectively delay parturition in sows in the presence of corpora lutea (WHITELY et al., 1990). The results have clearly confirmed that MPA is effective in maintaining gestation in sows even after PGF $2 \alpha$ injection and that intravaginal administration of MPA can be used in situations when delaying farrowing is desirable. Preventing parturitions in holidays and weekends is not the only applicability of gestagen in swine. Recently, it was reported that gestagens can be used to prevent early parturition (before 114 days of gestation) in sows, which decreases piglet losses (VANDERHAEGHE et al., 2011). Although it was previously reported that allyl trenbolone supplementation from day 110 to 115 of gestation increased the duration of farrowing (KIRKWOOD et al., 1985), the findings of this research showed that increasing gestation length to 115 days using IVDs containing MPA did not affect the farrowing duration in comparison to control sows farrowing at 113 days of gestation. Indeed, the time between the birth of the first and last piglet was in the range of previously reported data after PGF2 $\alpha$-induced parturition (DIEHL \& LEMAN, 1982), and similar to those reported after altrenogest treatment between days 110 and 113 of gestation (VANDERHAEGHE et al., 2011).

When the effect of IVDs to prevent farrowing during weekends was evaluated, no significant differences were observed between groups on the ratio of piglets born alive. Furthermore, duration of farrowing $(3.46 \pm 0.2 \mathrm{~h})$ in sows that received IVDs for $72 \mathrm{~h}$ was similar to those induced with PGF2 $\alpha$ in experiment $2(3.6 \pm 0.6 \mathrm{~h})$ and to previous reports (LUCIA JR et al., 2002; OLIVIERO et al., 2010). The average rate of dead piglets was also within the expected range, based on previous studies (VAN DIJK et al., 2005). Another study shown that prolonging the gestation to 116 days using i.m. injections of P4 did not significantly affect litter sizes at birth and at 19 days after farrowing (GOONERATNE et al., 1979). The average number of piglets born reported in that study was around 9, which represents about 5 piglets less than the average obtained with high prolific sows in the current study. This is particularly important, since it has been shown that litters having more than 12 piglets have higher risks of stillbirth (LUCIA JR et al., 2002). 
There was a relatively unexpected variation in the time of farrowing after MPA IVD withdrawal. Based on a previous study, the MPA halflife after device removal was $30 \mathrm{~h}$ in women treated with IVDs containing 100mg MPA (VICTOR \& JOHANSSON, 1976). However, the authors reported marked individual variation in MPA clearance, which could explain the degree of asynchrony in parturition observed after removing the IVDs. In another study, MPA was undetectable 5 to 7 days after IVD (100 and 200mg) withdrawal in women that wore IVDs for 21 days (HIROI et al., 1975). It is unlikely that the farrowing asynchrony is related to failure of PGF $2 \alpha$ in promoting luteolysis. Previous experiments demonstrated that sows fed MPA in the last days of gestation underwent spontaneous luteolysis and the endogenous progesterone levels decreased during the treatment period at the same time that in control animals (WHITELY et al., 1990). Similarly, it was demonstrated that exogenous progesterone supplementation between days 112 and 114 of gestation induced corpora lutea regression (GOONERATNE et al., 1979).

\section{CONCLUSION}

In conclusion, IVDs impregnated with MPA can delay parturition and avoid farrowing in weekends without having negative effects on the alive/total born piglets ratio. Additional studies are still necessary to further evaluate the effects of this technique on the reproductive performance of sows and overall viability of piglets.

\section{ACKNOWLEDGMENTS}

This study was supported by Conselho Nacional de Desenvolvimento Científico e Tecnológico (CNPq), Coordenação de Aperfeiçoamento de Pessoal de Nível Superior (CAPES) and Fundação de Amparo à Pesquisa do Estado do Rio Grande do Sul (FAPERGS).

\section{REFERENCES}

DE RENSIS, F. et al. Prostaglandin F2 $\alpha$ and control of reproduction in female swine: A review. Theriogenology, v. 77, n. 1, p. 1-11, 2012. Available from: <http://www.sciencedirect.com/ science/article/pii/S0093691X11003827>. Acessed: dec 12, 2012. doi: 10.1016/j.theriogenology.2011.07.035

DIEHL, J. R.; LEMAN, A. D. Effect of PGF2[alpha] and neostigmine on induction of parturition, farrowing interval and litter survival in swine. Theriogenology, v. 18, n. 6, p. 727-732, 1982. Available from: <http://www.sciencedirect.com/science/ article/pii/0093691X82900383>. Acessed: dec 12, 2012. doi: 10.1016/0093-691X(82)90038-3
GASPERIN, B. et al. Intravaginal progestagen for estrus and parturition control in sows. Pesquisa Agropecuária Brasileira, v. 46, n. 8, p. 961-964, 2011. Available from: <http://www.scielo.br/ pdf/pab/v46n8/24.pdf>.

GOONERATNE, A. et al. Control of Parturition in the Sow Using Progesterone and Prostaglandin. Australian Journal of Biological Sciences, v. 32, p. 587-596, 1979. Available from: <http:// www.publish.csiro.au/?act=view_file\&file_id=BI9790587.pdf $>$. Acessed: dec 12, 2012.

GUTHRIE, H. D. et al. Effect of Altrenogest and Lutalyse on Parturition Control, Plasma Progesterone, Unconjugated Estrogen and 13,14-Dihydro-15-Ketoprostaglandin F2 $\alpha$ in Sows. Journal of Animal Science, v. 65, n. 1, p. 203-211, 1987. Available from: $<$ http://jas.fass.org/content/65/1/203.short>. Acessed: dec 12, 2012.

HIROI, M. et al. Radioimmunoassay of serum medroxyprogesterone acetate (Provera ${ }^{\mathbb{1}}$ ) in women following oral and intravaginal administration. Steroids, v. 26, n. 3, p. 373-386, 1975. Available from: <http://www.sciencedirect.com/science/ article/pii/0039128X75900823 >. Acessed: dec 12, 2012. doi: $10.1016 / 0039-128 X(75) 90082-3$

HOLYOAKE, P. K. et al. Reducing pig mortality through supervision during the perinatal period. Journal of Animal Science, v. 73, n. 12, p. 3543-3551, 1995. Available from: <http:// jas.fass.org/content/73/12/3543.abstract $>$. Acessed: dec 12, 2012.

KING, G. J.; WATHES, D. C. Relaxin, progesterone and estrogen profiles in sow plasma during natural and induced parturitions. Animal Reproduction Science, v. 20, n. 3, p. 213-220, 1989. Available from: <http://www.sciencedirect.com/science/ article/pii/0378432089900869>. Acessed: dec 12, 2012. doi: 10.1016/0378-4320(89)90086-9

KIRKWOOD, R. N.; AHERNE, F. X. Increasing the predictability of cloprostenol-induced farrowing in sows. Swine Health and Production, v. 6, n. 2, p. 57-59, 1998. Available from: <http:// www.aasp.org/shap/issues/v6n2/v6n2p57.pdf>. Acessed: dec 12, 2012

KIRKWOOD, R. N. et al. The influence of allyl trenbolone (Regumate) on the timing, duration and endocrinology of parturition in sows. Animal Reproduction Science, v. 9, n. 2, p. 163-171, 1985. Available from: <http:/wwww.sciencedirect.com/ science/article/pii/037843208590020X>. Acessed: dec 12, 2012. doi: 10.1016/0378-4320(85)90020-X

LUCIA JR, T. et al. Risk factors for stillbirths in two swine farms in the south of Brazil. Preventive Veterinary Medicine, v. 53, n. 4, p. 285-292, 2002. Available from: <http://www.sciencedirect. com/science/article/pii/S0167587701002884>. Acessed: dec 12, 2012. doi: 10.1016/S0167-5877(01)00288-4

OLIVIERO, C. et al. Environmental and sow-related factors affecting the duration of farrowing. Animal Reproduction Science, v. 119 , n. 1, p. 85-91, 2010. Available from: <http://linkinghub. elsevier.com/retrieve/pii/S0378432009003017?showall=true $>$. Acessed: dec 12, 2012. doi: 10.1016/j.anireprosci.2009.12.009

PATTERSON, J. et al. Responses to delayed estrus after weaning in sows using oral progestagen treatment. Journal of Animal Science, v. 86, n. 8, p. 1996-2004, 2008. Available from: <http:// jas.fass.org/content/86/8/1996.abstract>. Acessed: dec 12, 2012. doi: $10.2527 /$ jas.2007-0440 
VAN DIJK, A. J. et al. Factors affecting duration of the expulsive stage of parturition and piglet birth intervals in sows with uncomplicated, spontaneous farrowings. Theriogenology, v. 64, n. 7, p. 1573-1590, 2005. Available from: <http://linkinghub.elsevier. com/retrieve/pii/S0093691X0500110X?showall=true $>$. Acessed: dec 12, 2012. doi: 10.1016/j.theriogenology.2005.03.017

VANDERHAEGHE, C. et al. Incidence and Prevention of Early Parturition in Sows. Reproduction in Domestic Animals, v. 46, n. 3, p. 428-433, 2011. Available from: <http://dx.doi.org/1 0.1111/j.1439-0531.2010.01685.x>. Acessed: dec 12, 2012. doi: 10.1111/j.1439-0531.2010.01685.x

VICTOR, A.; JOHANSSON, E. D. B. Pharmacokinetic observations on medroxyprogesterone acetate administered orally and intravaginally. Contraception, v. 14, n. 3, p. 319-329, 1976. Available from: <http://www.sciencedirect.com/science/ article/pii/0010782476900998>. Acessed: Dec 12, 2012. doi: $10.1016 / 0010-7824(76) 90099-8$
WHITELY, J. L. et al. Initiation of parturition and lactation in the sow: effects of delaying parturition with medroxyprogesterone acetate. Journal of Endocrinology, v. 124, n. 3, p. 475-484, 1990. Available from: <http://joe.endocrinology-journals.org/ content/124/3/475.abstract>. Acessed: dec 12, 2012. doi: 10.1677/ joe. 0.1240475

WILSON, M. E. et al. Effects of estrogen and prostaglandin on progesterone-delayed farrowing. Theriogenology, v. 32, n. 4, p. 577-583, 1989. Available from: <http:/www.sciencedirect.com/ science/article/pii/0093691X89902793>. Acessed: dec 12, 2012. doi: 10.1016/0093-691X(89)90279-3

WOOD, C. M.; KORNEGAY, E. T.; SHIPLEY, C. F. Efficacy of altrenogest in synchronizing estrus in two swine breeding programs and effects on subsequent reproductive performance of sows. Journal of Animal Science, v. 70, n. 5, p. 1357-1364, 1992. Available from: <http://jas.fass.org/content/70/5/1357.abstract $>$. Acessed: dec 12, 2012. 